\title{
Hopes for space station fade on Capitol Hill
}

Washington. The prospects of the planned US space station surviving in Congress this summer darkened further last week, when the State Department failed to convince a key subcommittee that the administration's plan to build the station jointly with Russia makes sense either politically, economically or technically.

With only a month to go before the House of Representatives may get the chance to vote to kill the programme, congressmen on the House space subcommittee appeared dismayed at the lack of detail on the Russian deal presented by the State Department witness, James Collins.

Collins is a senior adviser to Strobe Talbot, the architect of President Bill Clinton's policy towards the states of the former Soviet Union. But committee member Martin Hoke (Republican, Ohio) told Collins that the hearing felt like a "prefuneral" for the space station. "The administration has completely misunderstood the politics of this," said Hoke. "All you have to do is look at the numbers."

Last summer, the House voted by a majority of one to retain the station. Since then, some leading supporters of the project have publicly defected. "There is no groundswell of support for some form of 'new-age' relationship with the Russians," said Hoke, in a somewhat mocking reference to the administration's growing reputation for woolly and wishful thinking.

During testimony that congressional aides say indicated a lack of direction at the State Department, Collins said that the space station was supported by the administration primarily as a "US flagship for technology and science". He said that the Russian partnership would make it cheaper, as well as assisting relations with Russia.

But many congressmen are angry that the partnership makes the project reliant on Russia. They point out that the United States was never prepared to depend on Japan, Canada or the European Space Agency for any critical part of the station, despite having worked successfully with these partners for decades.

Further concerns include a recent admission by Dan Goldin, the administrator of the National Aeronautics and Space Administration (NASA), that Russian participation will save the United States less money than was originally promised, and that Russia is already attempting to increase to $\$ 650 \mathrm{mil}$ lion the $\$ 400$ million in US support promised for space collaboration in advance of the space station.

The space subcommittee and the Science Space and Technology Committee of which it is part do not have direct control over the space budget. But they have in the past been good friends of the space programme in general, and the station in particular; the lack of strong support on these committees therefore appears to bode ill for the project's survival.

George Brown (Democrat, California), the chairman of the full committee, has already threatened to withdraw his support from the project if NASA's overall budget is not maintained at the level he considers necessary to cover both the space station and a strong science programme. But station supporters are even more alarmed by the certain defection of James Sensenbrenner (Republican, Wisconsin), the senior Republican on the space subcommittee.

Sensenbrenner is likely to carry a number of uncommitted Republicans with him. This would deprive the station of bipartisan support, and leave the Democrat leadership with the unenviable task of persuading more Democratic congressmen to vote for billions of dollars of expenditure to shore up Clinton's Russian policy, which is already in trouble elsewhere.

"If Clinton thinks that foreign policy aspects will make Congress appropriate $\$ 17$ billion for this he's got another think coming," said Sensenbrenner after hearing Collins' testimony, referring to the space station's projected total cost to completion. "Unless this deal is renegotiated to make this an American space station, the time has come for Congress to cut its losses."

A vote on the station is likely to take place in the House in late May or early June. If this is lost, the damage will probably be fatal - although the administration could spend the summer manoeuvring with the more supportive Senate to try to rescue the project.

Colin Macilwain

\section{Austria's new research head favours applied science}

Munich. Austria should pay more attention to applied research, according to Arnold Schmidt, professor of physics at the Technical University in Vienna, who last month became president of Austria's science foundation, the Förderung der Wissenschaftlichen Forschung (FWF).

According to Schmidt, the quality of basic research has improved enormously over the past two decades, aided by increased government funding. But applied research has lagged seriously behind.

Schmidt has long been concerned with this problem. In 1988 he founded the Christian Doppler Society to link industry which funds the society - and the academic world. The society now runs 16 small applied research laboratories, each costing around ÖS3 million (US\$250,000) a year.

The laboratories define their own research projects, but their research areas have been chosen after canvassing industry for its views on the type of research that it would find most relevant to its future needs, such as catalysis and environmental biotechnology.
Schmidt wants to bring a flavour of the Doppler Society to the FWF. Although the foundation is mostly concerned with basic research, a small part (ÖS50 million) of its ÖS700 million funds is provided by the Austrian National Bank and is earmarked for industry-orientated basic research. Schmidt hopes to use the same method of canvassing industry as he introduced in the Doppler Society for allocating this money.

"At the moment, a committee decides

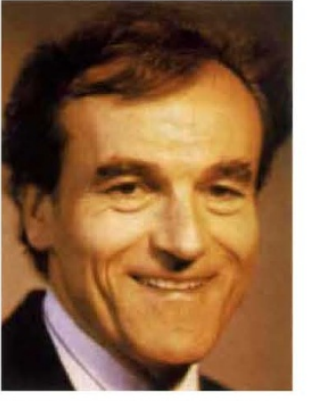

Schmidt: hoping for Doppler effect? if a research proposal has industrial relevance, and in most cases that is as far as it goes," he says. Actual industrial needs should be taken into account far more, he argues.

In order to influence seriously the research structure in Austria, Schmidt wants the next government (elections are due in
October) to establish a series of applied research institutes, along the lines of Germany's successful Fraunhofer institutes. The principle has general support. But it will have more difficulty in gaining financial support, as research funds will be stretched once Austria joins the European Union (EU) next year.

The government has not yet decided if it will increase its total research investment to take into account the obligatory contribution it will be required to make to the EU's fourth framework programme. Negotiations are taking place to determine how much of this will come from Austria's normal research budget, and how much will be new money.

Schmidt hopes that the government will be generous. Like many in Austria, he believes that the country's poor applied research base means it will be unable to compete effectively for EU research funds, which are mostly industrially orientated "Returns on [Austria's investment in EU programmes] will be low for at least the first few years," he says. 